\title{
ベンゾフェノン及び誘導体の塩素処理物の変異原性
}

\author{
山本 貴士 ${ }^{1)}$, 中島 大介 ${ }^{1)}$, 後藤 純雄 ${ }^{1)}$, 小野寺祐夫 ${ }^{2)}$, \\ 安原 昭夫 ${ }^{1)}$, 酒井 伸一 ${ }^{1)}$, 相馬 光之 ${ }^{3)}$ \\ "1国立環境研究所（テ305-8506 茨城県つくば市小野川16-2） \\ 2) 東京理科大学薬学部（₹278-8510 千葉県野田市山崎2641） \\ 3) 静岡県立大学大学院生活健康科学研究科（ $4422-8526$ 静岡県静岡市谷田52-1）
}

[平成16年 3 月 16 日受理］

\section{Mutagenicity of Chlorination Products of Benzophenone and Its Derivatives}

\author{
Takashi YAMAMOTO ${ }^{1)}$, Daisuke NAKAJIMA ${ }^{1)}$, Sumio GOTO ${ }^{1)}$, Sukeo ONODERA ${ }^{2)}$, \\ Akio YASUHARA ${ }^{1}$, Shin-ichi SAKAI ${ }^{1)}$ and Mitsuyuki SOMA ${ }^{3)}$ \\ ${ }^{1)}$ National Institute for Environmental Studies \\ (16-2 Onogawa, Tsukuba, Ibaraki 305-8506) \\ ${ }^{2)}$ Tokyo University of Science, Faculty of Pharmaceutical Sciences \\ (2641 Yamazaki, Noda, Chiba 278-8510) \\ ${ }^{3)}$ Graduate School of Nutritional and Environmental Sciences, University of Shizuoka \\ (52-1 Yada, Shizuoka, Shizuoka 422-8526)
}

[Received March 16, 2004]

\begin{abstract}
Summary
Six kinds of benzophenone and its derivatives were suspended in water and chlorinated with sodium hypochlorite at $\mathrm{pH} \mathrm{4,7}$, and 10. Chlorination products were extracted with dichloromethane and concentrated. Concentrated samples were subjected to mutagenicity tests and GC/MS analysis. Benzophenone (BP) and 2-hydroxy-4-octyloxybenzophenone (HOBP) did not consume chlorine. Contrary, 2,4-dihydroxybenzophenone (DHBP) and 2,2'-dihydroxy-4methoxybenzophenone (DHMBP) consumed almost all of chlorine. Several chlorinated compounds were detected by GC/MS analysis in the chlorination products, except BP. Many of them were chlorobenzophenones and chlorophenolic compounds.

Mutagenicity of chlorinated products was tested by Ames assay using Salmonella typhimurium TA98 and TA100. Chlorination products of DHBP, DHMBP, and 2,2'-dihydroxy4,4'-dimethoxybenzophenone (DHDMBP) showed relatively high mutagenicity. On the other hands, HOBP did not show mutagenicity. BP showed highly growth inhibition to TA98 and TA100. Generally, the mutagenicity of chlorination products of benzophenones was metabolisminactive, and increased at low $\mathrm{pH}$. The mutagenic potencies did not depend on the amounts of the major products. Thus, to evaluate the safety of chlorination products of landfill leachates properly, not only chemical analysis but also bio-assay technique should be needed.
\end{abstract}

Key words: benzophenones, plastic additives, chlorination, mutagenicity 


\section{1.はじめに}

今日, 我々の生活環境の至るところで多くのプラス チック製品が使用されており，またそれらには可塑郕, 難燃剤, 酸化防止剤, 紫外線吸収剤等多種類のプラス チック添加物が含まれている。こうしたプラスチック製 品が最終処分場に投菓された場合, 添加物が原体のま ま，あるいは何らかの変化を受けて浸出水や空気中に移 行する可能性がある。Yasuhara らは，1994～1995年に国 内19个所の処分場の浸出水を収集し, 含有される有機成

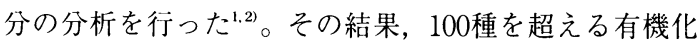
合物が検出され，その中には難燃郕である有機りン酸エ ステル, 可塑剤であるフタル酸エステルばかりでなく， 紫外線吸収剤のベンゾフェノン等のプラスチック添加物 が含まれていた。このベンゾフェノンは処分場浸出水 19 試料中15試料から検出されており，その濃度範囲は不検 出〜 $16.5 \mu \mathrm{g} /$ lであった ${ }^{1.2)}$ 。プラスチック添加剤である 紫外線吸収剤の代表的なものには，ベンゾフェノンとそ の誘導体がある。ベンゾフェノン系紫外線吸収剤の市場 規模は1995年で約550トンとされている3)。ベンゾフェノ ン類（BPs）は化粧品や石喃の保香料等としても使用さ れており》，こうした用途で使用された BPs は生活排水 などへ移行する可能性がある。都市河川水や底質中で BPs が検出されているが5,6)，こうした生活排水由来であ ると考えられる。

一方, 最終処分場や下水処理場には塩素殺菌設備があ り, 浸出水や処理水は河川等に放流する際には塩素処理 が施される。従って, 処分場浸出水や下水中の有機化合 物はそのまま放流されるか, あるいは添加された塩素と 反応し, 何らかの形に変化していることが考えられる。 以前, 我々はビスフェノール A の塩素処理について報告 した》。ビスフェノール A はポリカーボネート樹脂の原 料や塩化ビニル製品の安定剂等に使用されており, 処分 場浸出水や環境水中から頻繁に検出される物質である が1.28.9)，塩素水中で容易に塩素化されて塩素化ビスフェ ノール A や塩素化フェノール系化合物を生成することが 明らかとなった。

そこで本研究では，BPsが河川等に放流される前に塩 素処理が施され, その過程で塩素と反応して毒性を有す る物質に変化する可能性について検討した。即ち，6 種 類の BPs の塩素処理モデル実験を行い, その塩素処理生 成物の変異原性や生成物について検討した。

\section{2. 実験方法}

\section{1 試料と試薬}

ベンゾフェノン $(\mathrm{BP}), 2-$ ヒドロキシ-4-オクチルオキ シベンゾフェノン (HOBP), 2-ヒドロキシ-4-メトキシ ベンゾフェノン (HMBP), 2,4-ジヒドロキシベンゾ
フェノン (DHBP), 2,2'-ジヒドロキシ-4-メトキシベン ゾフェノン (DHMBP), 2,2'-ジヒドロキシ-4,4'-ジメ トキシベンゾフェノン (DHDMBP) の各BPsは，いずれ も和光純薬製の特級のものを使用した。これらの構造式 及びGC 保持時間を Table 1 に示した。次亜塩素酸ナトリ ウム溶液は和光純薬製の食品添加用のものを使用した。 亜硫酸ナトリウム, 水酸化ナトリウム, 塩酸は市販特級 品を使用した。ジクロロメタン, 塩化ナトリウム, 硫酸 ナトリウムは和光純薬製の環境分析用を使用した。精製 水は EDS- $5 \mathrm{~S}$ 純水製造システム（日本ミリポア製）で調 製したものを使用した。

\section{2 ベンゾフェノン類の塩素処理及び抽出}

実験条件を Table 2 に示す。BPsの塩素処理は，小野寺 らの方法 ${ }^{10)}$ 一部改変して行った。即ち, BPs（約 $100 \mathrm{mg}$ ）を $5 \mathrm{~m} \ell$ のメタノールに溶解して $1 \ell$ の精製水に 添加し, 試料溶液とした。次亜塩素酸ナトリウム溶液 （有効塩素量：110mg）を試料に添加し， $0.1 \mathrm{~mol} / \ell$ 塩酸ま たは水酸化ナトリウム溶液を直ちに加え, $\mathrm{pH}$ を $4,7,10$ に調整した。そのまま室温（約 $22^{\circ} \mathrm{C} ） て ゙ 60$ 分間摚拌を続 けて反応させた。

反応後, 反応溶液の一部（約 $2 \mathrm{~m} \ell$ ）を分取し, 残留塩 素計（水道機工製 CRT-1000）を用いて残留塩素を測定 した。残りの溶液には亜硫酸ナトリウム $1 \mathrm{~g}$ を加えて残 留塩素を除いた。得られた反応液に塩酸を加え酸性 $(\mathrm{pH}<3)$ とし，これに塩化ナトリウム $30 \mathrm{~g}$ を加えて溶 かし, ジクロロメタン $60 \mathrm{~m} \ell$ を加えて10分間振とう抽出 した。これを 3 回繰り返し, 得られたジクロロメタン抽 出液を合わせ，無水硫酸ナトリウムで脱水した。一部 (約 $1 \mathrm{~m} \ell)$ ） GC/MS 分析用に分取し，残りをロータリー エバポレーター (浴温 $\left.40^{\circ} \mathrm{C}\right)$ 及び窒素気流下で濃縮し た。これを $8 \mathrm{~m} \ell に$ 定容し，一定量を分取して弱い絰素 気流下でジクロロメタンを除き, タール状物質を得た。 これをDMSO に溶解し, Ames 試験（プレインキュベー ション法) ${ }^{11}$ に供した。

\section{2. $3 \mathrm{GC} / \mathrm{MS}$ 分析}

抽出液を $\mathrm{GC} / \mathrm{MS}$ により分析した。GC/MS 装置は Model 6890 plus GC/5973N MSD (アジレント製)を使 用した。キャピラリーカラムは HP-5MS (30m $\times$ $0.25 \mathrm{~mm} \times 0.25 \mu \mathrm{m}$ ，アジレント製）を使用した。昇温条 件は $60^{\circ} \mathrm{C}$ で 1 分保持, その後 $280^{\circ} \mathrm{C}$ まで $10^{\circ} \mathrm{C} /$ 分で昇温 し， 5 分間保持とした。キャリアガスは $\mathrm{He}$, 流速は毎 分 $1 \mathrm{~m} \ell$ とした。注入法はスプリットレス, 注入口温度 は $280^{\circ} \mathrm{C}$, 注入量は $1 \mu \ell$ とした。イオン化法は $\mathrm{EI}$, イオ ン化室温度は $230^{\circ} \mathrm{C}$ とした。定性分析はスキャン測定で 行い, 質量数範囲は $\mathrm{m} / \mathrm{z}=35 \sim 550$, スキャン速度は 1.4 スキャン/秒とした。定量分析は選択イオン検出 
Table 1 Chemical structure and GC retention times data of benzophenone and its derivatives tested in this work

\begin{tabular}{|c|c|c|c|c|c|c|}
\hline \multirow{2}{*}{$\begin{array}{c}\text { Chemicals } \\
\text { tested* }\end{array}$} & \multirow[t]{2}{*}{ M.W. } & \multicolumn{4}{|c|}{ Substituents** } & \multirow{2}{*}{$\begin{array}{c}\text { GC retention } \\
\text { time }(\min )\end{array}$} \\
\hline & & 2 & $2^{\prime}$ & 4 & $4^{\prime}$ & \\
\hline BP & 182 & $\mathbf{H}$ & $\mathbf{H}$ & $\mathbf{H}$ & $\mathbf{H}$ & 13.9 \\
\hline HOBP & 326 & $\mathrm{OH}$ & $\mathbf{H}$ & $\mathrm{OC}_{8} \mathrm{H}_{17}$ & $\mathbf{H}$ & 24.2 \\
\hline HMBP & 228 & $\mathrm{OH}$ & $\mathrm{H}$ & $\mathrm{OCH}_{3}$ & $\mathrm{H}$ & 18.1 \\
\hline DHBP & 214 & $\mathrm{OH}$ & $\mathrm{H}$ & $\mathrm{OH}$ & $\mathbf{H}$ & 18.9 \\
\hline DHMBP & 244 & $\mathrm{OH}$ & $\mathrm{OH}$ & $\mathrm{OCH}_{3}$ & $\mathrm{H}$ & 19.3 \\
\hline DHDMBP & 274 & $\mathrm{OH}$ & $\mathrm{OH}$ & $\mathrm{OCH}_{3}$ & $\mathrm{OCH}_{3}$ & 22.0 \\
\hline
\end{tabular}

* $\mathrm{BP}=$ benzophenone, HOBP = 2-hydroxy-4-octyloxybenzophenone, $\mathrm{HMBP}=$ 2-hydroxy-4-methoxybenzophenone, DHBP = 2,4-dihydroxybenzophenone DHMBP = 2,2'-dihydroxy-4-methoxybenzophenone, DHDMBP = 2,2'-dihydroxy-4,4'dimethoxybenzophenone.

** Structure and numbering scheme of benzophenone are shown in below.<smiles>O=C(c1ccccc1)c1ccccc1</smiles>

Table 2 Reaction conditions for the chlorination of benzophenones

\begin{tabular}{|c|c|c|c|c|c|c|c|c|}
\hline \multirow[t]{2}{*}{ Compounds } & \multirow[t]{2}{*}{ Initial pH } & \multicolumn{2}{|c|}{ Initial BP amount } & \multirow[t]{2}{*}{ Molar ratio } & \multirow{2}{*}{$\begin{array}{c}\text { Chlorine } \\
\text { residue }(\mathrm{mg} / \mathrm{l})\end{array}$} & \multirow{2}{*}{$\begin{array}{c}\text { Extract } \\
\text { amount (mg) }\end{array}$} & \multirow{2}{*}{$\begin{array}{l}\text { BP residue* } \\
\text { (mg) }\end{array}$} & \multirow{2}{*}{$\begin{array}{c}\text { Product } \\
\text { amount }(\mathrm{mg})\end{array}$} \\
\hline & & $(\mathrm{mg} / \mathrm{l})$ & $(\mathrm{mmol} / \mathrm{l})$ & & & & & \\
\hline \multirow[t]{3}{*}{ BP } & 4.15 & 104.3 & 0.572 & 5.42 & 103 & 84.4 & 83.0 & 1.5 \\
\hline & 7.27 & 104.2 & 0.572 & 5.43 & 104 & 77.6 & 87.2 & 0.0 \\
\hline & 9.80 & 107.9 & 0.592 & 5.24 & 117 & 84.0 & 84.4 & 0.0 \\
\hline \multirow[t]{3}{*}{ HOBP } & 3.93 & 102.4 & 0.314 & 9.89 & 101 & 77.7 & 30.4 & 47.3 \\
\hline & 7.06 & 102.7 & 0.315 & 9.86 & 88 & 76.4 & 36.1 & 40.3 \\
\hline & 9.96 & 102.6 & 0.314 & 9.87 & 105 & 92.0 & 35.6 & 56.4 \\
\hline \multirow[t]{3}{*}{ HMBP } & 4.17 & 101.5 & 0.445 & 6.98 & 39 & 72.2 & 34.8 & 37.5 \\
\hline & 7.11 & 101.2 & 0.443 & 7.00 & 30 & 53.0 & 39.5 & 13.5 \\
\hline & 9.93 & 101.6 & 0.445 & 6.97 & 44 & 81.5 & 31.1 & 50.4 \\
\hline \multirow[t]{3}{*}{ DHBP } & 3.89 & 103.9 & 0.485 & 6.40 & 0 & 60.5 & 7.6 & 52.8 \\
\hline & 7.16 & 103.7 & 0.484 & 6.41 & 0 & 62.0 & 5.4 & 56.6 \\
\hline & 10.37 & 108.0 & 0.504 & 6.15 & 0 & 58.4 & 8.1 & 50.4 \\
\hline \multirow[t]{3}{*}{ DHMBP } & 3.89 & 101.2 & 0.414 & 7.49 & 0.55 & 78.4 & 19.1 & 59.2 \\
\hline & 7.05 & 101.6 & 0.416 & 7.46 & 0 & 78.5 & 19.1 & 59.3 \\
\hline & 10.12 & 101.5 & 0.416 & 7.47 & 0 & 68.3 & 14.2 & 54.1 \\
\hline \multirow[t]{3}{*}{ DHDMBP } & 3.84 & 102.2 & 0.373 & 8.33 & 86 & 75.2 & 63.8 & 11.3 \\
\hline & 7.01 & 100.7 & 0.367 & 8.45 & 64 & 81.5 & 65.5 & 16.0 \\
\hline & 9.91 & 103.2 & 0.376 & 8.25 & 29 & 73.5 & 56.8 & 16.6 \\
\hline
\end{tabular}

Initial Chlorine concentration: $110 \mathrm{mg} / 1(3.10 \mathrm{mmol} / \mathrm{l})$; Reaction temperature: $22-23^{\circ} \mathrm{C}$.

* BP residues were determined by GC/MS. 
(SIM) 測定で行い，モニターイオン質量数は $\mathrm{m} / \mathrm{z}=182$ (BP), 326 (HOBP), 227 (HMBP), 213 (DHBP), 244 (DHMBP), 274 (DHDMBP) とした。

\section{4 変異原性試験}

試験菌株には Salmonella typhimurium TA98 ${ }^{12)}$ 及び $\mathrm{TA} 100^{12}$ を用いた。滅菌したアルミキャップ付試験管に 試料の DMSO 溶液と菌懸濁液を取り, S9mix 添加条件 (+S9) ではS9mixを, 無添加条件 $(-\mathrm{S} 9)$ では $0.1 \mathrm{~mol} / \ell$ $\ell$ 酸ナトリウム緩衝液を加えた。 $37^{\circ} \mathrm{C}$ で20 分間プレインキュベーション後, 軟寒天を加えて混合し てプレート上に広げた。 $37^{\circ} \mathrm{C} て ゙ 48$ 時間培養後, 復帰コロ ニー数を計測した。 S9mix はコファクターなどの入った 凍結乾燥品と S9溶液のセット（オリエンタル酵母工業 社製エームステスト用S9／コファクターAセット）を用 いて調製した。試料溶液を溶媒対照を含めて DMSO で 7 段階に希釈し (dose), 各 dose あたり 2 枚のプレート を用いて試験した。また，陽性対照として＋S9条件では ベンゾ $[\mathrm{a}]$ ピレン $(\mathrm{BaP}),-\mathrm{S} 9$ 条件では $2-(2-フ リ ル)-3-$ (5-ニトロ-2-フリル) アクリルアミド（AF2）を用いた。 変異原性の判定では, dose-response が良好なもので, 復 帰コロニー数が自然復帰コロニー数の $1.5 \sim 2$ 倍のもの を疑陽性，2 倍以上のものを陽性とした。また必要に応 じてプレート表面を顕微鏡観察し，菌の生育阻害作用が 生じているかどうか判定した。

\section{3. 結果と考察}

\section{1 ベンゾフェノン類の塩素との反応}

用水・廃水の塩素処理では, 通常, 溶存有機物量に応 じて $5 \sim 30 \mathrm{mg} / \ell$ となるように塩素ガスの注入が行われ る。しかし, 用水・廃水の塩素ガス注入口周辺では一時 的に100〜 $1000 \mathrm{mg} /$ lになることもあり，摫拌によって 5 $30 \mathrm{mg} / \ell$ の平均值に達する。従って, 今回の実験では塩 素濃度を現実に起こり得る $100 \mathrm{mg} / \ell$ とした。

ベンゾフェノン類 (BPs) の塩素処理における残留塩 素量を Table 2 に示す。BP と HOBP はいずれの $\mathrm{pH}$ でも ほとんど塩素を消費しなかった。逆に, DHBPと DHMBP は完全に塩素を消費した。HMBP では $100 \mathrm{mg}$ の 基質あたり約66～80mg の塩素が消費された。DHDMBP の塩素消費量は, pH 4 では $24 \mathrm{mg} / 100 \mathrm{mg} \mathrm{BPs,} \mathrm{pH} 7$ では $46 \mathrm{mg} / 100 \mathrm{mg}$ BPs, pH10では $81 \mathrm{mg} / 100 \mathrm{mg}$ BPs と反応時 の $\mathrm{pH}$ による差が顕著であり, 塩基性側で消費量が増え る傾向が認められた。芳香環の塩素置換は求電子反応で あり，水酸基やメトキシ基等の電子供与性の置換基が存 在する場合に反応が促進される ${ }^{13)}$ 。従って, HOBPを除 くベンゾフェノン誘導体は BPよりも容易に塩素化さ れ，塩素を消費したものと考えられる。HOBPは2-位に 水酸基を有するものの，4-位のオクチルオキシ基による
立体障害のために塩素化が阻害され，塩素を消費しな かったものと考えられる。

BPs の残存量を Table 2 に示す。塩素を消費しなかっ た BPでは初期量の $80 \%$ 以上がジクロロメタン抽出物中 に回収されたが，塩素を完全に消費したDHMBPや DHBP ではジクロロメタン抽出物中の残存量は初期量の $25 \%$ 未満と少なかった。その他の BPs では, 残存量は初 期量の30〜 65\%程度であった。

\section{2 ベンゾフェノン類の塩素処理生成物中の化合物}

$\mathrm{BPs}$ の塩素処理反応物を推定するため, GC/MS 分析を 行った。Fig. 1 にDHMBPの各 pHでの塩素処理生成物の トータルイオンクロマトグラム（TIC）の例を示した。

塩素処理では, 各 BPs の原体は全ての塩素処理水から 検出されたが，BPは原体以外のピークを認めなかった。 このことは 3.1 の結果と一致している。

各 BPs の塩素化物は, BP 以外の試料で確認された。 HOBP DHBP の塩素化物のマススペクトルにおいて, ベンゾイル基 $\left(\mathrm{C}_{6} \mathrm{H}_{5} \mathrm{CO}-\right)$ に由来する $\mathrm{m} / \mathrm{z}=77,105$ の フラグメントイオンがみられることから, 塩素置換は置 換基のある側の芳香環で起きていることが分かった。ま た, DHMBPの塩素化物のマススペクトルにおいて, ヒ ドロキシベンゾイル基 $\left(\mathrm{HOC}_{6} \mathrm{H}_{4} \mathrm{CO}-\right)$ に由来する $\mathrm{m} / \mathrm{z}$ =93，121のピークが確認されたことから，塩素置換は メトキシ基のある側の芳香環で起きていることが分かっ た。

また，HMBP や DHMBP，DHDMBP の塩素処理生成 物中にトリクロロ-3-メトキシフェノール（保持時間 12.8分), DHBP の塩素処理生成物中にクロロ-1,3-ジヒ ドロキシベンゼン類が確認された。これらは，塩素化の 進んだ BPsがさらに塩素化され，ベンゾフェノン骨格部 分で開裂して生成したものと考えられる。

その他, 未同定のピークとして, HMBP の塩素処理生 成物では $\mathrm{M}^{+}=264$ のモノロロ体化合物 (18.6分) や $\mathrm{M}^{+}=330$ のトリクロロ体化合物 (20.1分) が推定され た。また, DHBP の塩素処理生成物では $\mathrm{M}^{+}=214$ のジク ロロ体化合物（13.5分）や $\mathrm{M}^{+}=248$ のトリクロロ体化合 物 (14.2分) が推定された。DHMBP の塩素処理生成物 では $\mathrm{M}^{+}=310$ のジクロロ体化合物（保持時間22.8分）や $\mathrm{M}^{+}=344$ のトリクロロ体化合物 (24.3分) が推定され た。これらは水酸基が酸化されたキノン体と考えられ る。DHDMBP の塩素処理生成物では, メチル化体の化 合物 (22.4分) やアセチル化体の化合物 (22.8分) が推 定された。

以上の GC/MS 分析結果より, ベンゾフェノン誘導体 の塩素化では，置換基のある側の芳香環で段階的に塩素 化が起こり, 続く塩素化によりベンゾフェノン骨格が開 裂して塩素化フェノール性化合物を生成する等の経路を 
経て分解が進行することが分かった。

\section{3 ベンゾフェノン類塩素処理生成物の変異原性} ベンゾフェノン類塩素処理生成物の変異原性試験結果 を Table 3 に，また用量一反応曲線の例を Fig. 2 に示す。
なお，今回使用した 6 種類のBPs（未反応物）は, TA98，TA100株に対して変異原性を示さなかった。ま ず，塩素処理反応液の抽出物について，反応に供した BPs 量あたりの变異原性（rev./mg BPs）を求めた。

$\mathrm{BP}$ の塩素処理生成物は, 初期 $\mathrm{pH}$ によらず TA98及び

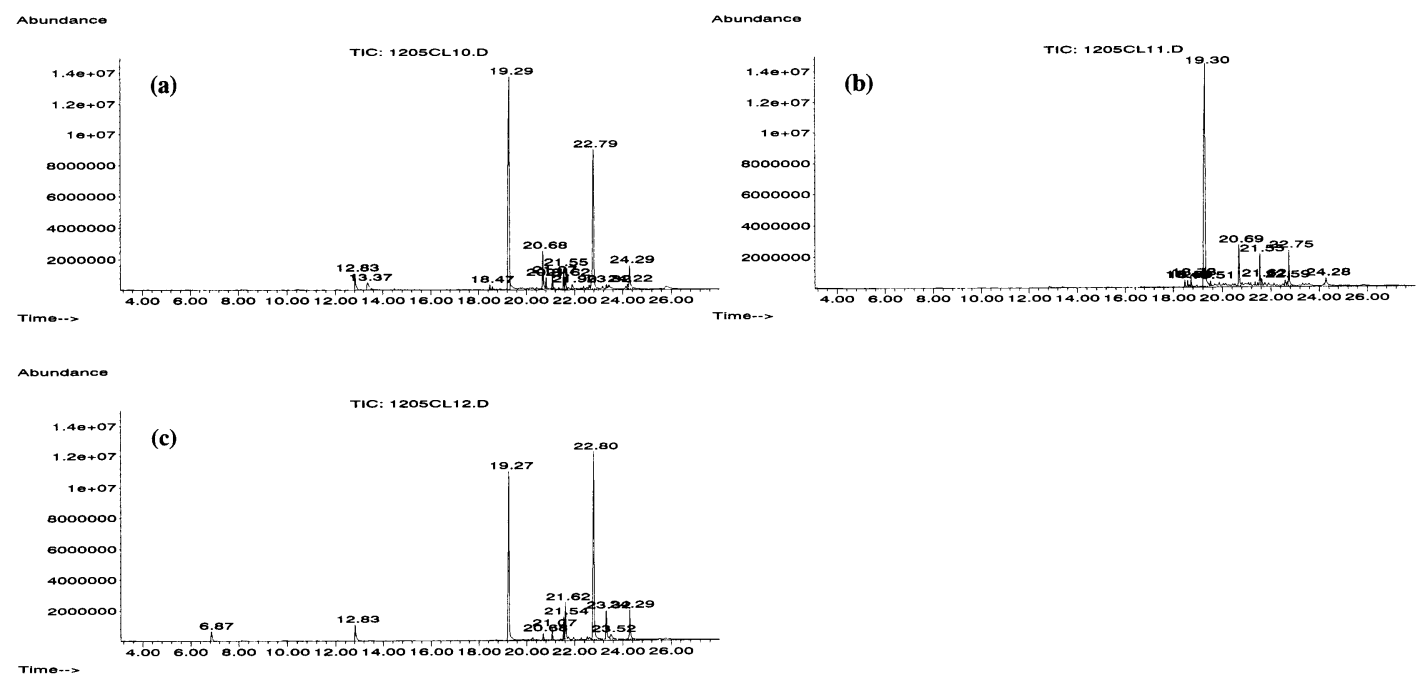

Fig. 1 Total ion chromatograms of the extracts of chlorine-treated DHMBP solutions

(a) Treated at $\mathrm{pH} 4$; (b) treated at $\mathrm{pH} \mathrm{7}$; (c) treated at $\mathrm{pH} 10$

Table 3 Mutagenicity of the chlorination products of benzophenones

\begin{tabular}{|c|c|c|c|c|c|c|c|c|c|}
\hline \multirow[b]{2}{*}{ Compounds } & \multirow[b]{2}{*}{ Initial $\mathrm{pH}$} & \multicolumn{4}{|c|}{ Mutagenicity (revartants/mg-BP) ${ }^{*}$} & \multicolumn{4}{|c|}{ Mutagenicity (revartants/mg-products) ${ }^{* *}$} \\
\hline & & TA98-S9 & TA98+S9 & TA100-S9 & TA100+S9 & TA98-S9 & TA98 + S9 & TA100-S9 & TA100+S9 \\
\hline \multirow[t]{3}{*}{ BP } & 4.15 & ND & ND & ND & ND & ND & ND & ND & ND \\
\hline & 7.27 & ND & ND & ND & ND & ND & ND & ND & ND \\
\hline & 9.80 & ND & ND & ND & ND & ND & ND & ND & ND \\
\hline \multirow[t]{3}{*}{ HOBP } & 3.93 & ND & ND & ND & ND & ND & ND & ND & ND \\
\hline & 7.06 & ND & ND & ND & ND & ND & ND & ND & ND \\
\hline & 9.96 & ND & ND & ND & ND & ND & ND & ND & ND \\
\hline \multirow[t]{3}{*}{ HMBP } & 4.17 & $480^{t}$ & ND & $3,100^{t}$ & ND & $1,300^{t}$ & ND & $8,500^{t}$ & ND \\
\hline & 7.11 & $430^{t}$ & ND & $4,200^{t}$ & ND & $3,200^{t}$ & ND & $31,000^{t}$ & ND \\
\hline & 9.93 & ND & ND & ND & ND & ND & ND & ND & ND \\
\hline \multirow[t]{3}{*}{ DHBP } & 3.89 & $9,900^{t}$ & ND & $44,000^{t}$ & ND & $19,000^{t}$ & ND & $86,000^{t}$ & ND \\
\hline & 7.16 & $4,500^{t}$ & ND & $39,000^{t}$ & ND & $8,100^{t}$ & ND & $71,000^{t}$ & ND \\
\hline & 10.37 & $4,500^{t}$ & ND & $14,000^{t}$ & ND & $9,600^{t}$ & ND & $30,000^{t}$ & ND \\
\hline \multirow[t]{3}{*}{ DHMBP } & 3.89 & $7,400^{t}$ & $450^{t}$ & $57,000^{t}$ & $2,800^{t}$ & $13,000^{t}$ & $770^{t}$ & $97,000^{t}$ & $4,700^{t}$ \\
\hline & 7.05 & $8,400^{t}$ & $450^{t}$ & $90,000^{t}$ & $3,000^{t}$ & $14,000^{t}$ & $770^{t}$ & $150,000^{t}$ & $5,100^{t}$ \\
\hline & 10.12 & $1,800^{t}$ & $390^{t}$ & $46,000^{t}$ & 740 & $2,400^{t}$ & $500^{t}$ & $60,000^{t}$ & 960 \\
\hline \multirow[t]{3}{*}{ DHDMBP } & 3.84 & $190^{t}$ & 70 & $12,000^{\prime}$ & 290 & $1,700^{t}$ & 640 & 100,000 & 2,600 \\
\hline & 7.01 & $560^{t}$ & 60 & $2,400^{t}$ & 290 & $3,500^{t}$ & 400 & $15,000^{t}$ & 1,800 \\
\hline & 9.91 & $1,500^{\mathrm{t}}$ & 40 & 1,800 & 220 & $9,100^{t}$ & 240 & 11,000 & 1,300 \\
\hline
\end{tabular}

${ }^{*}$ revertants $/ \mathrm{mg}$ of initial benzophenones; ${ }^{* *}$ revertants $/ \mathrm{mg}$ of chlorination products which deduced the weight of unchlorinated benzophenones from that of chlorination mixture extract. ND: Mutagenicity was not observed within $1000 \mu \mathrm{g} / \mathrm{plate}$ for HOBP, $500 \mu \mathrm{g} / \mathrm{plate}$ for HMBP, $250 \mu \mathrm{g} /$ plate for BP and $100 \mu \mathrm{g} /$ plate for DHBP. ; t: Toxicity was observed. Italic: pseudo-mutagenic. 

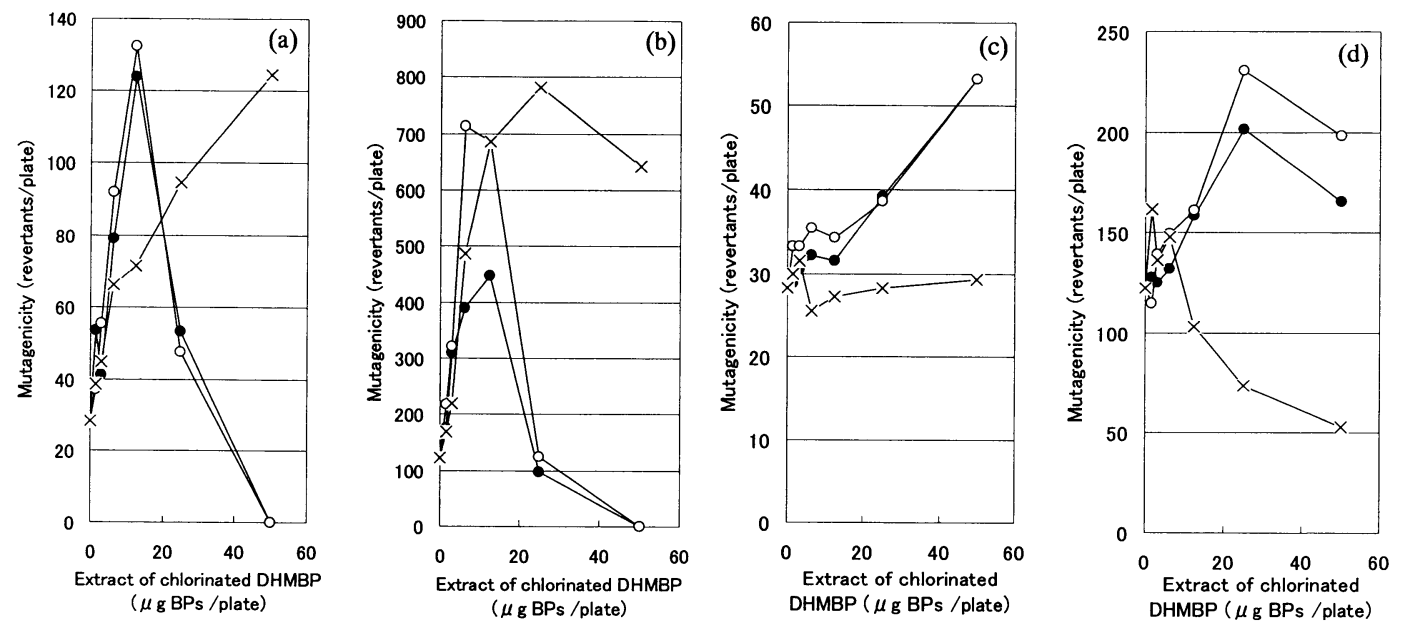

Fig. 2 Dose-response curves obtained for dichloromethane extracts of chlorine-treated DHMBP solutions by Salmonella preincubation assay

(a) TA98, -S9; (b) TA100, -S9; (c) TA98, +S9; (d) TA100, +S9

Symbols: $-\mathrm{pH} 4, \bigcirc \mathrm{pH} 7, \times \mathrm{pH} 10$

TA100菌株に対して強い生育阻害作用を示した。3．1 の項で記述したように，BPはほとんど塩素を消費せず， GC/MS 分析でも BP 以外のピークは検出されなかったの で，この結果は BP 原体の有するサルモネラ菌に対する 生育阻害によるものと考えられる。HOBP の塩素処理生 成物は, 試験した濃度範囲で生育阻害, 変異原性ともに 示さなかった。HMBP の塩素処理生成物は初期 $\mathrm{pH}$ が 4, 7 の試料で TA98株及び TA100株の S9mix 無添加条件 下（－S9）で弱い変異原性を示した（擬陽性）。DHBPの 塩素処理生成物は TA98株及び TA100株-S9で変異原性 を示し, 初期 $\mathrm{pH}$ が低いほど变異原性が強かった。 DHMBP, DHDMBP の塩素処理生成物もTA98株及び TA100株で変異原性を示したが，+S9よりも一S9で変異 原性が強かった。DHDMBP の塩素処理生成物は酸性側 で変異原性が強かったが，DHMBPでは $\mathrm{pH} 7$ で最も強 い変異原性を認めた。

これらの抽出物には未反応の BPs も残っており，それ らの量を $\mathrm{GC} / \mathrm{MS}$ により定量し, 抽出物重量から差し引 いて求めた塩素処理生成物の変異原比活性 (revertants/mg products) も求めた（Table 3 )。基本的な 傾向は変わらず, DHDMBP, DHMBP, DHBP の塩素処 理生成物で陽性, HMBP の塩素処理生成物で擬陽性を示 した。陽性を示したものの内では, 総じて DHMBP と DHBP で比較的変異原性が強く, DHDMBP はこれらよ りも若干弱いという結果となった。

以上より, DHMBP, DHBP, DHDMBP の塩素処理生 成物の変異原性の特徴として, (i) TA98株, TA100株の いずれにおいても変異原性を示す，(ii） S9mixによる代
謝を受けると変異原性は減少する, (iii) 酸性側で変異 原性が強い，ということが示唆された。これらの結果 は，水中有機物の塩素処理で生成する化合物が，一般 に，TA100に感受性が高く，S9mixによる代謝を必要と しない，いわゆる，塩基対置換型の直接变異原物質であ るとする報告 ${ }^{10)}$ と一致している。

\section{4 ベンゾフェノン類の塩素処理によって生成する 变異原性物質の構造推定}

Table 4 に, 各塩素処理生成物の GC/MS 分析によって 検出されたピークとその強度をまとめて示した。HMBP の塩素処理生成物の場合, 各 $\mathrm{pH}$ の変異原性の強さと検 出ピークとの関係から, 保持時間18.6分の $\mathrm{M}^{+}=264$ の ピークまたは20.1分の $\mathrm{M}^{+}=330$ のピークが，その活性本 体である可能性が考えられた。これに対してDHBPの場 合, TA98（-S9）に対する活性が $\mathrm{pH} 4$ の場合に高いが, この活性は保持時間14.2分の $\mathrm{M}^{+}=248$ のピークによる可 能性もあるが，詳細は不明である。また，DHMBP 及び DHDMBP の場合は, 変異原性強さのパターンと一致す る検出ピークは認められず，微量であるが強い変異原性 を示す化合物が生成していることが強く示唆された。

以上のように，BPs の塩素処理によって生成する変異 原性物質は，一般にその生成量が比較的多い主要成分に よるものではないことが示唆された。このことは, 塩素 処理された浸出水等の安全性評価の際に, GC/MS 等の 化学分析だけではなく，バイオアッセイを併用すること の必要性を示唆するものである。今後，今回使用した BPs の中で最も強い活性を示した DHMBP 反応生成物に 
Table 4 Peaks of the chlorination products of benzophenones identified by GC/MS measurements

\begin{tabular}{|c|c|c|c|c|c|}
\hline & \multirow{2}{*}{$\begin{array}{l}\text { r.time } \\
(\mathrm{min})\end{array}$} & \multirow{2}{*}{ presumed structure } & \multicolumn{3}{|c|}{ relative peak intensity } \\
\hline & & & $\mathrm{pH} 4$ & pH 7 & pH 10 \\
\hline \multirow{8}{*}{ HMBP } & 7.9 & benzoic acid & 2 & 4 & 1 \\
\hline & 12.8 & trichloro-3-methoxyphenol & 2 & 1 & 2 \\
\hline & 18.1 & HMBP & 47 & 75 & 35 \\
\hline & 18.6 & $\mathrm{M}^{+}=264$, include $\mathrm{Cl}$ & 5 & 4 & \\
\hline & 19.5 & $\mathrm{HMBP}-\mathrm{Cl}$ & 19 & 8 & \\
\hline & 20.1 & $\mathrm{M}^{+}=330$, include $\mathrm{Cl}_{3}$ & 3 & 2 & \\
\hline & 20.4 & $\mathrm{HMBP}-\mathrm{Cl}_{2}$ & 6 & 4 & 60 \\
\hline & 20.6 & HMBP-Cl & 5 & 2 & \\
\hline \multirow{5}{*}{ DHBP } & 7.9 & benzoic acid & 4 & 4 & 3 \\
\hline & 13.5 & $\mathrm{M}^{+}=214$, include $\mathrm{Cl}_{2}$ & 5 & 2 & \\
\hline & 14.2 & $\mathrm{M}^{+}=248$, include $\mathrm{Cl}_{3}$ & 6 & & \\
\hline & 18.9 & DHBP & 37 & 19 & 39 \\
\hline & 20.5 & $\mathrm{DHBP}-\mathrm{Cl}_{2}$ & 41 & 70 & 51 \\
\hline \multirow{11}{*}{ DHMBP } & 6.9 & $\mathrm{M}^{+}=208$, include $\mathrm{Cl}_{4}$ & & & 2 \\
\hline & 12.8 & trichloro-3-methoxyphenol & 3 & & 3 \\
\hline & 13.4 & $\mathrm{M}^{+}=178$, include $\mathrm{Cl}_{3}$ & 3 & & \\
\hline & 19.3 & DHMBP & 42 & 59 & 29 \\
\hline & 20.7 & DHMBP-Cl & 4 & 6 & 1 \\
\hline & 21.1 & $\mathrm{M}^{+}=388$, include $\mathrm{Cl}_{4}$ & 1 & & 1 \\
\hline & 21.5 & DHMBP-Cl 2 & 2 & 4 & 3 \\
\hline & 21.6 & DHMBP-Cl & 2 & 1 & 5 \\
\hline & 22.8 & $\mathrm{M}^{+}=310$, include $\mathrm{Cl}_{2}$ & 23 & 6 & 38 \\
\hline & 23.3 & DHMBP-Cl 3 & 1 & & 4 \\
\hline & 24.3 & $\mathrm{M}^{+}=344$, include $\mathrm{Cl}_{3}$ & 4 & 2 & 5 \\
\hline \multirow{8}{*}{ DHDMBP } & 6.9 & $\mathrm{M}^{+}=208$, include $\mathrm{Cl}_{3}$ & & & 1 \\
\hline & 11.5 & dichloro-1,3-dimethoxybenzene & 0 & & \\
\hline & 12.6 & trichloro-1,3-dimethoxybenzene & 0 & & \\
\hline & 12.8 & trichloro-3-methoxyphenol & & & 6 \\
\hline & 22.0 & DHDMBP & 86 & 89 & 80 \\
\hline & 22.4 & DHDMBP-methyl & 2 & 3 & 3 \\
\hline & 22.8 & DHDMBP-acetyl & 4 & 3 & 3 \\
\hline & 23.8 & $\mathrm{M}^{+}=356$, include $\mathrm{Cl}_{2}$ & & & 2 \\
\hline
\end{tabular}

ついて，その分画等による活性本体の探索について，検 討を進める予定である。

\section{要 約}

6 種類のベンゾフェノン及びその誘導体を $\mathrm{pH} 4,7,10$ に調整した水中で塩素処理を行い, 抽出物の変異原性試 験と GC/MS 分析を行った。ベンゾフェノン (BP) と2ヒドロキシ-4-オクチルオキシベンゾフェノン（HOBP）
は塩素を消費しなかったが，2,4-ジヒドロキシベンゾ フェノン (DHBP) と2,2'-ジヒドロキシ-4-メトキシベ ンゾフェノン（DHMBP）は完全に塩素を消費した。BP の塩素処理生成物を除いて GC/MS 分析によって含塩素 化合物が検出され, 主要成分は塩素化ベンゾフェノン 類，塩素化フェノール性化合物であった。

変異原性試験は Salmonella typhimurium TA98及び TA100を用いたAmes 法によって行った。DHMBP, 
DHBP, 2,2’-ジヒドロキシ-4,4'-ジメトキシベンゾ フェノン (DHDMBP) の塩素処理生成物は比較的高い 変異原性を示した。しかし, HOBP の塩素処理生成物は 変異原性を示さなかった。なお, 塩素処理生成物を生成 しなかった BP 原体は，TA98及び TA100に強い生育阻害 を示した。ベンゾフェノン類の塩素処理生成物の変異原 性は, 総じて S9mix を加えると減少するか消失し, 低 $\mathrm{pH}$ で高くなる傾向を示した。変異原性の強さは GC/MS で検出された主要成分の量とは必ずしも対応しておら ず, 浸出水等の塩素処理生成物の安全性評価の際に, $\mathrm{GC} / \mathrm{MS}$ 等の化学分析だけではなく, バイオアッセイを 併用することの必要性が示唆された。

\section{文 献}

1) Yasuhara, A., Shiraishi, H., Nishikawa, M., Yamamoto, T., Uehiro, T., Nakasugi, O., Okumura, T., Kenmotsu, K., Fukui, H., Nagase, M., Ono, Y., Kawagoshi, Y., Baba, K. and Noma, Y.: Determination of organic components in leachates from hazardous waste disposal sites in Japan by gas-chromatography-mass spectrometry. J. Chromatogr. A, 774, 321-332 (1997)

2) Yasuhara, A., Shiraishi, H., Nishikawa, M., Yamamoto, T., Nakasugi, O., Okumura, T., Kenmotsu, K., Fukui, H., Nagase, M. and Kawagoshi, Y.: Organic components in leachates from hazardous waste disposal sites. Waste Manage. Res., 17, 186197 (1999)

3）大手良之：紫外線吸収剤 (UVA), pp56, 「高分子添 加剂の新展開」, 日本化学会, 高分子学会編, 日刊 工業新聞社, 東京 (1998)

4) Wang, S.-P. and Lee, W.-T.: Determination of benzophenones in a cosmetic matrix by supercritical fluid extraction and capillary electrophoresis. $J$. Chromatogr. A, 987, 269-275 (2003)

5) Benfenati, E., Toro, N.D., Fanelli, R., Lualdi, G.,
Tridico, R., Stella, G., Buscaini, P. and Stimilli, L.: Characterization of organic and inorganic pollutants in the Adige river (Italy). Chemosphere, 25, 16651674 (1992)

6) Ricking, M., Schwarzbauer, J. and Franke, S.: Molecular markers of anthropogenic activity in sediments of the Havel and Spree Rivers (Germany). Water Res., 37, 2607-2617 (2003)

7) Yamamoto, T. and Yasuhara, A.: Aqueous chlorination of bisphenol A-formation of chlorinated bisphenol A congeners and phenolic compounds. Chemosphere, 46, 1215-1223 (2002)

8) Yamamoto, T., Yasuhara, A., Shiraishi, H. and Nakasugi, O.: Bisphenol A in hazardous waste landfill leachates. Chemopshere, 42, 415-418 (2001)

9) Lee, H.B. and Peart, T.E.: Determination of bisphenol $\mathrm{A}$ in sewage effluent and sludge by solidphase and supercritical fluid extraction and gas chromatography/mass spectrometry. J. AOAC Intern., 83, 290-297 (2000)

10）小野寺祐夫, 吉松慶一郎, 斉藤寿代, 内田 彩: フェノール化合物の塩素処理による变異原物質の生 成挙動及びそれらの変異原物質生成能, 衛生化学, 44, 289-299 (1998)

11) Yahagi, T., Nagao, M., Seino, Y., Matsushima, T., Sugimura, T. and Okada, M.: Mutagenicities of Nnitrosoamines on Salmonella. Mutation Res., 48, 121-130 (1977)

12) Maron, D.M. and Ames, B.N.,: Revised methods for Salmonella mutagenicity test. Mutation Res., 113, 173-215 (1983)

13） McMurry, J. (伊東 溦, 児玉三明, 荻野敏夫, 深澤 義正, 通 元夫訳) : 置換芳香環における置換基の 効果, pp574-578, 「有機化学 第 5 版」, 東京化学 同人，東京 (2001) 